This article was downloaded by: [University of Nottingham]

On: 22 March 2014, At: 09:53

Publisher: Routledge

Informa Ltd Registered in England and Wales Registered Number: 1072954

Registered office: Mortimer House, 37-41 Mortimer Street, London W1T 3J H, UK

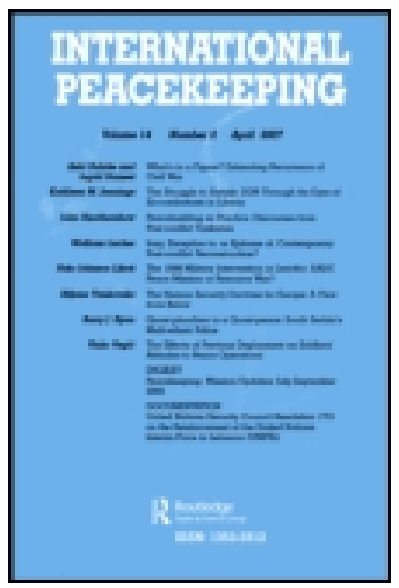

\title{
International Peacekeeping
}

Publication details, including instructions for authors and subscription information:

http:/ / www. tandfonline.com/loi/ finp20

\section{China's Charm Offensive and Peacekeeping: The Lessons of Cambodia - What Now for Sudan? \\ Miwa Hirono \\ Published online: 15 J un 2011.}

To cite this article: Miwa Hirono (2011) China's Charm Offensive and Peacekeeping: The Lessons of Cambodia - What Now for Sudan?, International Peacekeeping, 18:3, 328-343, DOI: $10.1080 / 13533312.2011 .563097$

To link to this article: http:// dx. doi.org/ 10.1080/ 13533312.2011.563097

\section{PLEASE SCROLL DOWN FOR ARTICLE}

Taylor \& Francis makes every effort to ensure the accuracy of all the information (the "Content") contained in the publications on our platform. However, Taylor \& Francis, our agents, and our licensors make no representations or warranties whatsoever as to the accuracy, completeness, or suitability for any purpose of the Content. Any opinions and views expressed in this publication are the opinions and views of the authors, and are not the views of or endorsed by Taylor \& Francis. The accuracy of the Content should not be relied upon and should be independently verified with primary sources of information. Taylor and Francis shall not be liable for any losses, actions, claims, proceedings, demands, costs, expenses, damages, and other liabilities whatsoever or howsoever caused arising directly or indirectly in connection with, in relation to or arising out of the use of the Content.

This article may be used for research, teaching, and private study purposes. Any substantial or systematic reproduction, redistribution, reselling, loan, sublicensing, systematic supply, or distribution in any form to anyone is expressly 
forbidden. Terms \& Conditions of access and use can be found at http:// www.tandfonline.com/page/terms-and-conditions 


\title{
China's Charm Offensive and Peacekeeping: The Lessons of Cambodia - What Now for Sudan?
}

\author{
MIWA HIRONO
}

\begin{abstract}
China's participation in UN peacekeeping is often viewed as a part of a global 'charm offensive' aimed at enhancing China's image in host countries. However, when viewed in the light of its support for dictatorial regimes in those host countries, do Chinese peacekeeping efforts improve the perceptions local populations have of China? This article examines changes in Cambodian perceptions of China during the UN Transitional Authority in Cambodia (UNTAC) from 1992 to 1993. It argues that China's peacekeeping contribution to UNTAC helped to overcome negative perceptions of that country rooted in its support of the Khmer Rouge before 1992. The key to overcoming current negative perceptions is to project an image of Chinese neutrality with respect to all parties in a civil war. This article concludes by discussing the implication of this argument with regard to China's peacekeeping in Sudan from 2006 to the present, and suggesting that China will need to be more attentive to the needs of other warring factions in the north-south and Darfur conflicts.
\end{abstract}

\section{Introduction: China's Peacekeeping from Local Perspectives}

The politics of image have been important to China for at least the last two decades. In the 1990s, the People's Republic of China (PRC) engaged in 'peripheral diplomacy' (zhoubian waijiao, 周边外交), seeking a favourable image in Southeast and East Asia, thereby securing its borders and enabling it to rapidly develop economically. As China's rise continued to increase its reach globally in the 2000s, the government made cautious efforts to project the idea that it does not threaten the world. These efforts are demonstrated by such policy discourses in China as 'peaceful development', 'harmonious world', 'soft power' and 'responsible power'. Chinese officials and analysts see peacekeeping as an important component of its 'charm offensive' aimed at enhancing its image in host countries. ${ }^{1}$

However, reports indicate that there are problems of distrust between the Chinese and local populations in several host countries, including Sudan. A representative example is the kidnapping of Chinese oil workers in Sudan in October 2008. ${ }^{2}$ This was a consequence of China's close relations with the regime in Khartoum. In Sudan, China has provided the Khartoum government in the north with political, security and economic support, including arms used in the north-south and Darfur conflicts. ${ }^{3}$ The conflict between the northern and southern regions persisted over two decades from 1983 to 2005, and resulted in an estimated two million deaths, four million internally displaced people, and about half a million refugees. ${ }^{4}$ In Darfur, the Sudanese government and its Janjaweed 
militia have conducted mass killings and ethnic cleansing since 2003, resulting in the deaths or disappearances of as many as 200,000 people. $^{5}$ China's close relations with a genocidal regime was not unprecedented. In Cambodia, the Chinese government provided the Khmer Rouge with political, economic and military support. ${ }^{6}$ For three years and nine months (April 1975 to January 1979), the Khmer Rouge carried out the massacre that led to the death of more than 1.5 million people, no less than a fifth of the Cambodian population, and the regime forced many others into hard labour. ${ }^{7}$

When local populations perceive that China is aiding a genocidal regime, how do they then perceive China's peacekeeping? Does it help to wipe out negative impressions and help local peoples to reconstruct a more favourable image of China? In other words, does China's 'charm offensive' work in complex conflicts? This article addresses these questions by examining how local Cambodian perceptions of China changed as a result of the Chinese peacekeeping contribution to the UN Transitional Administration in Cambodia (UNTAC) from 1992 to 1993 . The term 'charm offensive' began to appear in the literature in the early 2000s and may not apply directly to the 1992-93 period. However, the fact that Cambodia was a crucial part of China's peripheral diplomacy in the early 1990s, which aimed to gain China a favourable image among local populations (the same diplomatic objective as China's 'charm offensive' in a global context in the 2000s), implies that China's Cambodia policy can be understood as a precursor to the 'charm offensive'. The Cambodian case is chosen because the country has experienced one of the worst genocides in history, and local populations saw China as a supporter of the dictatorial regime. Local Cambodian suspicion of the PRC as a prelude to the UNTAC operation resembles the current case in Sudan, where the Chinese face the problem of local distrust in southern Sudan and Darfur. Therefore, it is useful to examine China's peacekeeping in Cambodia and to consider what that experience can offer about ways in which the PRC could address the issue of local distrust in southern Sudan and Darfur.

The article argues that, as a result of the peacekeeping operation, China's 'charm offensive' in Cambodia was successful in transforming negative local perceptions of China's past into more positive ones. This argument comes with an important caveat. The reason local Cambodians changed their perceptions in favour of China is not just that the PRC provided infrastructure to facilitate local Cambodian state-building and economic development - the reason often assumed in discussion of the 'hearts and minds' strategy of peace operation, as mentioned below. In fact, the more important factor is that China had engaged in diplomacy with multiple actors prior to the peacekeeping period - it had close relations with the Khmer Rouge, but simultaneously also with the King Father Sihanouk, who was a widely respected and still is a popular figure in Cambodia. The approach taken in Cambodia has significant policy implications for China's peacekeeping in Sudan in the 2000s onwards. To gain local trust in areas substantially governed by factions other than the Khartoum government, China's diplomacy with Sudan needs to be more neutral, and attentive to the needs of other warring factions, such as the southern Sudan autonomous 
government, the Justice and Equality Movement (JEM) and the Sudan Liberation Army in Darfur.

The following section begins by briefly discussing the theoretical literature on local perspectives in peace operations. This is followed by an examination of the changes in local perceptions of China and of its peacekeeping efforts. The focal point of the analysis is how local Cambodians perceived China's apparently Janus-faced attitude towards their country - supporting a genocidal regime on the one hand, and contributing to keeping peace on the other. To investigate local attitudes and perceptions, research was undertaken in Cambodia from August to September 2009. This consisted of two parts: first, semi-structured interviews with Cambodian intellectuals, former UNTAC personnel and government officials in Phnom Penh (a total of 27), and six local village leaders on National Road No.6, which Chinese peacekeepers repaired during part of their mission (from April 1992 to September 1993); and, second, a questionnaire survey with Cambodian students at the Royal Cambodian Armed Forces' College of Social Sciences and Languages. This was chosen because it was expected that Cambodian military officers would have specialized knowledge of the country's international military ties, including of the Chinese military contribution to UNTAC. As revealed in more detail later, China's activities during UNTAC are not necessarily well known among local Cambodians because China chose to keep a low profile. However, the images of China among those who did have the chance to come into contact with Chinese peacekeepers generate some interesting implications regarding the later discussion of China's 'charm offensive' project in the context of Sudan in the 2000s. The author carried out a questionnaire survey among those who were expected to have a better knowledge of China's contribution. The questionnaire was structured and its questions formulated on the basis of general Cambodian perceptions of China gathered from the semi-structured interviews.

\section{Local Perspectives}

The peacekeeping literature suggests that local perspectives should be considered of foremost importance because they relate closely to the legitimacy of peacekeeping operations. ${ }^{8}$ For example, the United Nations Peacekeeping Operations: Principles and Guidelines states that

[ $\mathrm{t}$ ] he manner in which a United Nations peacekeeping operation conducts itself may have a profound impact on its perceived legitimacy on the ground. The firmness and fairness with which a United Nations peacekeeping operation exercises its mandate, the circumspection with which it uses force, the discipline it imposes upon its personnel, the respect it shows to local customs, institutions and laws, and the decency with which it treats the local people all have a direct effect upon perceptions of its legitimacy. ${ }^{9}$

The tendency to pay more attention to local perspectives has increased since the problematic interventions in Iraq and Afghanistan. ${ }^{10}$ The International 
Security Assistance Force (ISAF) in Afghanistan attracts much criticism because of its increasing involvement in counter-insurgency, which has led to significant civilian casualties and 'has greatly reduced local support for ISAF - and with it perceptions of the operation's legitimacy, both locally and internationally' ${ }^{11}$

In this context, military provision of aid and infrastructure is often understood as a means to win the 'hearts and minds' of local people, thereby raising the legitimacy of a peacekeeping operation and leading to mission success. For example, Merriam Mashatt, Maj.-Gen. Daniel Long and James Crum mention that 'infrastructure adds "arms and legs" to strategies aimed at winning "hearts and minds." Infrastructure is fundamental to moving popular support away from prewar or during-conflict loyalties and to moving spoilers in favor of postwar political objectives'. ${ }^{12}$ The majority of China's peacekeepers are military engineers, and its main peacekeeping contribution can be seen as the building of infrastructure. Theoretically, therefore, Chinese peacekeeping should be popular among local populations in operational areas. ${ }^{13}$

However, as the examples of Iraq and Afghanistan clearly suggest, the provision of aid and infrastructure does not directly translate into gaining local trust. Instead, as is often claimed by NGO workers in conflict zones, whether outside forces can gain local trust depends on how 'neutral' local people perceive them. ${ }^{14}$ NGOs assert that the 'shield' on which they rely to enable them to operate safely in conflict areas is the neutrality of the organizations and their independence in a civil war. This raises significant concerns with regard to China's peacekeeping because China was seen as having close relations with dictatorial regimes - for example, the Pol Pot regime in Cambodia and the Omar alBashir government in Sudan. ${ }^{15}$ For whatever reasons the PRC has supported these regimes, ${ }^{16}$ what matters when the PRC attempts to enhance local perceptions of China through its peacekeeping activity is the question of how local populations perceive China's relationship to the dictatorial regime, and how its peacekeeping affects such perceptions.

Indeed, the importance of local perceptions informs the pluralist approach to the study of peace. In part, 'a crisis of legitimacy' of the liberal paradigm has led the study of peacekeeping and peacebuilding to pay more attention to local agency. ${ }^{17}$ Oliver Richmond also contends that the 'universal and hegemonic discourse' of liberal peace has produced peacebuilding failures, and that peace needs to be 'contextualised more subtly, geographically, culturally, in terms of identity, and the evolution of the previous socio-economic polity'. ${ }^{18}$ In this context, 'peace' needs to be researched in terms not only of how it is achieved, but also, more fundamentally, of what it means (or what 'they' mean if one takes the pluralist notion of 'peaces') and whose peace needs more attention. ${ }^{19}$ Interdisciplinary perspectives that draw upon sociology, anthropology, human geography and cultural studies enable one to examine the sources of legitimacy of peace operation from local perspectives. ${ }^{20}$

This article is informed by these theoretical studies and complements them by offering an explanation of why the Cambodians changed their perceptions of China after the latter's peacekeeping efforts. As will be discussed below, 
Cambodian perceptions shifted not just because of infrastructures built by Chinese peacekeepers. More importantly, the shift occurred because of China's dual political support in Cambodia. Before I discuss this in more detail, the following section will briefly set the broader political context of China-Cambodia relations prior to the UNTAC operation in 1992.

\section{China's Dual Political Support in Cambodia}

The PRC has been one of the key actors in Cambodia's international and domestic political scene since well before the end of the Cold War. At the time of the Vietnam conflict (1955-75), Sihanouk was under pressure from China and North Vietnam to assist their communist forces, and had ceded the northeast of Cambodia to North Vietnam. The PRC also waged a limited and ineffective war in early 1979 against Vietnam, which had invaded Cambodia the previous year, installed a new communist government in Phnom Penh and ousted the Khmer Rouge from the capital. ${ }^{21}$

China maintained close relations with two different warring factions in Cambodia simultaneously, one represented by the Khmer Rouge and the other by Sihanouk. To the Khmer Rouge, China sent political, economic and military support for nearly two decades from the early 1970s to the end of the 1980s, including the period in which this faction committed genocide. ${ }^{22}$ At the same time, China twice allowed Sihanouk to form a government in exile in Beijing, and once to seek refuge there. ${ }^{23}$ Chinese backing of the Khmer Rouge in Phnom Penh and Sihanouk in Beijing from April 1976 to December 1978 is particularly interesting, because the two factions opposed each other. When the Khmer Rouge forced Sihanouk out of office, China gave assistance to the prince and provided him refuge in China, while supporting the Khmer Rouge and continuing to be 'its only link to the outside world'. ${ }^{24}$

China's dual political support for both sides continued until 1993, although military assistance to the Khmer Rouge was severed in 1990. During the peace process (1988-92) and the UNTAC period (1992-93), China attempted to sustain Khmer Rouge involvement in the transitional Cambodian government. It did so despite the Khmer Rouge's uncooperative attitude to the peace process and failure to fulfil its commitment to a ceasefire. Most states attempted to exclude the Khmer Rouge from a national election but China consistently maintained that the Khmer Rouge should be included. For example, the UN Security Council resolution 783 on 30 November 1992 stipulated sanctions against the Khmer Rouge and an election in which all parties but the Khmer Rouge would take part. China was the only country among the Security Council's 15 members that abstained. The Ambassador to the UN, Li Daoyu, commented in 1992 that sanctions and three-party elections 'will further increase differences and sharpen contradictions and could consequently lead to new, complicated problems in the Cambodian situation'. ${ }^{25}$ However, by May 1993 China had completely severed relations with the Khmer Rouge. This is demonstrated by the fact that the Khmer Rouge offered no apology to China when it unintentionally killed two Chinese peacekeepers and 
injured four in the Chinese camp at Skun village in Kompong Cham province on 21 May $1993 .^{26}$

\section{Cambodian Perspectives on China}

Since China had supported the Khmer Rouge, the Cambodian people had formed very negative perceptions of China before UNTAC. These perceptions were reinforced particularly by a smear campaign against China undertaken by the Vietnamese-installed government in the 1980s. It disseminated a pamphlet, Crime of Beijing Chinese Hegemony Enlargement and Servants Pol Pot, Eang Sary, Khieu Samphan during 1975-1978 [sic], arguing that China had been supporting the Khmer Rouge during the period of genocide. This pamphlet resulted in the Cambodian population believing that China was actually behind the genocide. ${ }^{27}$ Against this background, how did Cambodians perceive China during and after the period of UNTAC?

As far as Cambodian perceptions are concerned, China's objective of enhancing its image was met to a limited extent only. Of 27 interviewees in Phnom Penh, nine were not even aware of the Chinese contribution to UNTAC, even though most of them were working for, or closely with, UNTAC. The questionnaire survey at the Royal Cambodian Armed Forces' College of Social Sciences and Languages also indicates that only 14 out of 48 respondents $(29.2$ per cent) were aware that China had contributed military personnel to the UNTAC mission, despite the author's initial expectation that military college students would know more about military-to-military ties with China.

The level of knowledge about China's participation was very different from, for example, knowledge about Japan's participation, though the type and scale of their respective contributions were similar. Both countries sent engineer units: two battalions of 400 troops totalling 800 from China, and two battalions of 600 troops totalling 1,200 from Japan. ${ }^{28}$ All of the interviewees knew that the Japanese had made a significant contribution to the UNTAC operation, but more than half of the interviewees were completely unaware of the role the Chinese had played in the operation. The other half knew of a Chinese presence, but many had only vague memories of where the Chinese contingent had worked and what they had done. Likewise, the loss of two Japanese (UN volunteer Nakata Atsushi and superintendent Takada Haruyuki) in April and May 1993, respectively, is well known among Cambodians. However, the loss of two Chinese (Chen Zhiguo and Yu Shili, both from engineering battalions) in May 1993 is less well known.

The high profile of the Japanese forces, in large part, was derived from having Akashi Yasushi as Special Representative of the UN Secretary-General for Cambodia. Moreover, Japanese foreign policy at that time aimed to make a visible international contribution. ${ }^{29}$ In contrast, China's involvement was invisible because it did not greatly endeavour to gain publicity about its military presence in Cambodia. This may relate first to a concern that China's military presence might have reminded the Cambodians of the support China had given to the Khmer Rouge. In fact, 'keep a low profile' (tao guang yang hui, 搯光养䀲) was one of China's broader foreign policy stances in the decade after 1989. This 
policy was formulated by Deng Xiaoping when the West tried to establish a new world order at the end of the Cold War and China needed to focus on its domestic economic development while avoiding any perception that it was a challenger in the new order. ${ }^{30}$ Its peacekeeping contribution to UNTAC was consistent with this policy, and was literally obscured 'beneath blue berets'.

However, the author's interviews with Cambodian intellectuals and government officials who had been directly engaged with the Chinese peacekeepers, or were aware of the Chinese contribution, reveal a different story. The views expressed in those interviews have important implications with regard to the later discussion of Sudan in this article because, by contrast, China in the 2000s wants to be seen globally. It is embarking on a global 'charm offensive' to try to reassure the view that China's rise is benign in nature.

Those Cambodians with a knowledge of Chinese peacekeepers were favourably disposed towards them, owing mainly to the peacekeepers' diligent work ethic. ${ }^{31}$ Furthermore, the Chinese engineering contribution to UNTAC was invaluable to the overall operation, given that they contributed approximately 19 per cent of UNTAC's entire engineering troop complement. ${ }^{32}$ As correctly suggested by the above-mentioned theoretical literature on the importance of building infrastructure in peacekeeping, local villagers who lived alongside national roads repaired by the Chinese peacekeepers also praised them because they 'fixed the road very well and I could go to the nearby town more quickly'; 'they worked effectively and diligently'; 'they were very friendly and smiling at us'; and 'they had good discipline'. ${ }^{33}$ Some villagers shared favourable stories of their encounters with the Chinese soldiers. Villagers appreciated their help, so they would for instance bring them local produce. On another occasion, Chinese peacekeepers, bored one evening, visited a villager's house to watch TV with them. Not all the UN troops were able to create such a popular reputation as the Chinese peacekeepers. The Bulgarians, for example, were cited as major offenders, as some of them were reportedly very rude towards local Cambodians. ${ }^{34}$

Furthermore, several interviews with villagers along National Road No.6, which Chinese engineering battalions renovated, revealed more specific examples of cooperation between the Chinese and local people. This road goes through Khompon Thom Province, where the Khmer Rouge was still engaging in attacks against the local population and the police force during the UNTAC period. The Chinese peacekeepers needed force protection against the Khmer Rouge, but the UNTAC mandate allowed peacekeepers to use weapons only in self-defence. Therefore, armed local police and a group of armed villagers gathered to protect the engineers. In interviews villagers expressed their trust in the Chinese. ${ }^{35}$ One villager commented that 'it was great that the Chinese did not bring weapons other than those to be used for self-defence. If they had done, that would have created a sense of doubt towards them'. ${ }^{36}$

Despite the fact that China had supported the Khmer Rouge historically, 24 (out of 33) Cambodian interviewees who knew about the Chinese peacekeepers tended to be very positive. They were asked how they had developed such positive views even though they had experienced the terror of the Khmer Rouge's reign 
and had known that China had earlier supported the Khmer Rouge. Several villagers suggested that it was because China had close relations with Sihanouk. The questionnaire survey also reveals the importance of the PRC's relations with Sihanouk. Based on the perspectives commonly given by the interviewees, the questionnaire suggested the following six possible reasons for the PRC to have contributed its troops to UNTAC: (1) an altruistic view of Cambodia's development and stability; (2) to make amends or apologies for what it had done to Cambodia in the past; (3) to use the opportunity to make economic inroads into Cambodia; (4) because of close relations with the King Father Sihanouk; (5) because of Western pressure after Tiananmen Square in June 1989; and (6) some other reason. Respondents could choose multiple answers. As Figure 1 indicates, the overwhelming majority (91.3 per cent) chose option 4, the Sihanouk factor, as the reason for China's contribution to UNTAC. From the perspective of those who survived the genocide, Chinese support for the figure whom they respected highly was seen as an important prerequisite to China's ability to build a relationship with the new Cambodia.

In addition to the Sihanouk factor, another prominent and common view related to 'forgiveness', which ten out of 33 interviewees explained as being a part of Cambodian culture or religion. They repeatedly stated that Chinese support for the Khmer Rouge 'is a story of the past', and 'Cambodia is a Buddhist country. We can forgive others'. ${ }^{37}$ Such sentiments may have been declaratory rather than genuine belief, but the theme of forgiveness was consistently expressed in interviews. Some interviewees even considered that one of the reasons China sent its peacekeepers to Cambodia was to make amends or apologize for what it had done in the past. In the questionnaire survey, also, more than a quarter of respondents chose the option, 'China wanted to make amends or apologize for what it had done to Cambodia in the past' (28.3 per cent). This

FIGURE 1

CAMBODIAN PERCEPTIONS OF CHINA'S MOTIVES FOR UNTAC PARTICIPATION

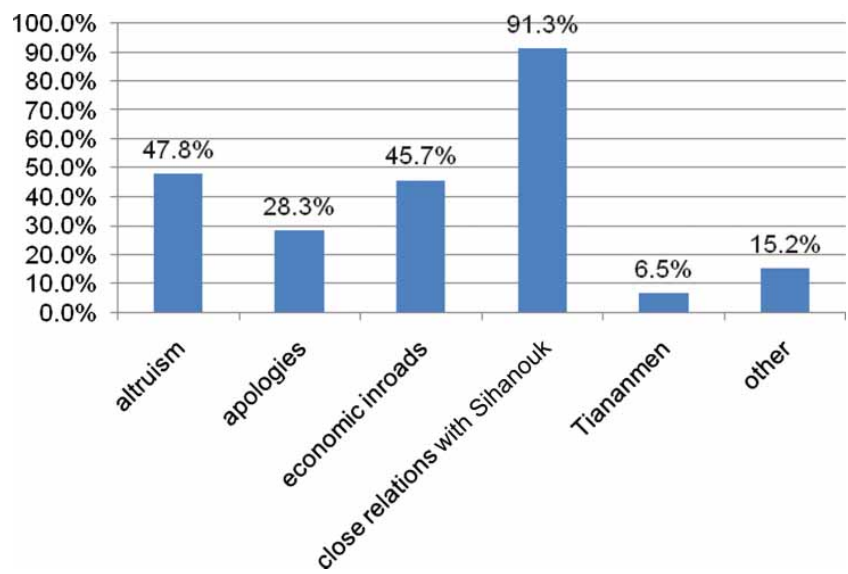

Source: Author's questionnaire survey conducted at the Royal Cambodian Armed Forces' College of Social Sciences and Languages, 2009. 
contrasts with general theoretical observations on the importance of providing infrastructure for gaining local trust, which ignore local agency and assumes that local populations are content simply with material benefits. The interviews and questionnaire survey suggest that an anthropological perspective allows an exploration of the nature of interactions between local community members and outsiders, when considering issues around the local distrust of peacekeepers. ${ }^{38}$

Another finding from the questionnaire survey is divergence between Cambodian and certain international perceptions of Tiananmen Square as the reason for China's deployment of peacekeepers. Some analysts have posited that the most plausible explanation for China's participation in UNTAC is that the country sought to improve its international reputation, which had been severely damaged by the violent suppression of the demonstrations in Tiananmen Square. ${ }^{39}$ However, only 6.5 per cent of respondents chose this as a reason.

In short, important factors that led to the improvement of China's image are: first, the PRC's enduring support for Sihanouk, Cambodia's legitimate figurehead; second, the Cambodian interpretation that China came to make amends or apologize for its past deeds in providing support to the Khmer Rouge, which Cambodians could forgive; and third (relevant only to those who interacted with Chinese peacekeepers), Chinese peacekeepers' diligent work ethic. These three factors were essential in improving China's image among Cambodian local populations.

\section{Implications with Regard to China's Peacekeeping in Sudan}

Approximately two decades have passed since UNTAC operated in Cambodia. Various changes have taken place in both international and Chinese policies and practices. Together with increased use of Chapter VII mandates, peacekeeping practices have become more robust and complex. China's peacekeeping policy has changed from advocating mere participation in traditional peacekeeping to engaging in a range of UN peace operations, by taking a more flexible stance in relation to the notion of sovereignty. ${ }^{40}$ These operations include peace enforcement in United Nations Operation in Somalia II (UNOSOM II) from 1993 to 1995, and peace support operations in Liberia, Côte d'Ivoire and the Democratic Republic of Congo among others in the 2000s. ${ }^{41}$ Chinese diplomacy has also changed. As mentioned earlier, China's diplomacy is much more visible, and its 'charm offensive' is attracting much more attention in the global politics of the new century.

However, some important aspects of China's peacekeeping practices remain similar to those of the China of 20 years ago. Among these is the practice of preferring host government consent. No matter how local populations and/or other states view particularly illegitimate governments, China insists on obtaining host government consent as a prerequisite for UN Security Council approval of a peacekeeping operation. ${ }^{42}$ Therefore, for example, China viewed as necessary the gaining of endorsement from such dictatorial regimes as the Khmer Rouge and al-Bashir before it decided to contribute to UN peacekeeping operations in 
Cambodia and Sudan. Those local populations that were victims of these dictatorial regimes retain deeply ingrained negative impressions of China's support for these regimes. China's peacekeeping operations in Cambodia and Sudan are thus similar in this sense. But a countervailing factor is that, throughout China's 20-year involvement in UN peacekeeping, not a single Chinese peacekeeper has been charged with misconduct, and the Chinese work ethic has been praised by many policymakers and analysts. ${ }^{43}$ Based on the above analysis of Cambodian attitudes towards China, how could the Chinese government and its peacekeepers gain the trust of local populations in Sudan, and thereby successfully carry out a 'charm offensive' there?

In Sudan, China is seen as a part of the problem behind two civil wars: one between Arab northern Sudan and Christian southern Sudan (1983-2005); and the other between northern Sudan and Darfur (2003 to the present). ${ }^{44}$ The restriction of oil exports to Western states since the 1980s has led the Sudanese government to forge closer relations with China. ${ }^{45}$ People in southern Sudan regard China as being too closely linked to the al-Bashir government. China is seen as focused on obtaining access to oil, and by extension on supporting the Khartoum government. For that reason, a UN peacekeeper suggested, the Chinese were 'not perceived as neutral by some of the population, primarily those of the pro-Sudanese People's Liberation Army' (SPLA). ${ }^{46}$

However, the situation has changed in southern Sudan since 2008. China has been developing closer relations with the semi-autonomous government in southern Sudan. As the 2005 Comprehensive Peace Agreement sets out, a referendum in southern Sudan was undertaken in January 2011 to decide whether it would secede from the north to form an independent nation. There are also abundant oil resources in the southern region, and discussion is already underway between China and Kenya on building a pipeline to Kenyan ports. ${ }^{47}$ Oil will not have to go through the Port of Sudan in the north, and this has led China to reconsider its position in relation to the north-south conflict. In September 2008, China established the Chinese Consulate-General in Juba, the capital of the southern Sudan region. The Consulate-General has delivered aid directly to southern Sudan. ${ }^{48}$ Consul-General Zhang Qingyang met with Riek Machar, Deputy Chairman of the Sudan People's Liberation Movement (SPLM) and Vice-President of the semi-autonomous government of southern Sudan in November 2009 and September 2010, exchanging views on such issues as strengthening cooperation between the two parties. ${ }^{49}$ Until 2008, the Chinese government had regarded the SPLM as a 'rebel group', and had not sought to form any meaningful relationship with it. China has, however, changed its diplomatic stance on southern Sudan in order 'to navigate Sudan's uncertain political future'. ${ }^{50}$

With regard to Darfur, according to a peacekeeper who was stationed at Nyala in Darfur province in late 2007, the Chinese were particularly concerned about being targeted by 'rebels' in acts of retribution against the Sudanese government. Chinese oil investment supported the Khartoum government, and therefore striking at the Chinese contingent could have been a way of attacking the government. Although there has been no such attack, it appears that there is a continuing 
and deep concern among the Chinese peacekeepers that one could occur. ${ }^{51}$ Unlike in the case of China's dual diplomacy in Cambodia and in the north-south conflict in Sudan, there has been no interaction between Chinese peacekeepers and 'rebel groups' in and around Darfur, such as the JEM and the Sudan Liberation Army. In October 2007, the JEM attacked the facilities of a Chinese-led business consortium, the Greater Nile Petroleum Operating Company, in the Defra oilfields in the Kordofan region, and demanded that China withdraw support from the Sudanese government. ${ }^{52}$ As Jonathan Holslag states, China's 'pure state-centric approach fails to consider other important actors in the region of Darfur. A peace mission will need to deal as much with private militias and rebel movements as with regular forces, and neglecting this will constrain its impact'. ${ }^{53}$

Can China's peacekeeping presence change perceptions of China as the 'friend of a dictatorial regime', as held by a Darfurian? The Cambodian case suggests that the answer to this question depends on whether the PRC can maintain its political neutrality by supporting multiple actors, including a figure who is seen as legitimate by local populations, and whether local cultures will facilitate reconciliation or forgiveness. Establishing and maintaining relations with more than one actor does not necessarily mean that China will need to move away from the principle of sovereignty. It is possible to establish and maintain relationships with other actors in a civil war without contradicting that principle. China managed to maintain relations with both the Khmer Rouge and Sihanouk in Cambodia while adhering to the principle of sovereignty by recognizing only one government at a time. After all, the maintaining of relationships can take a variety of forms. China has been doing this in the southern Sudan, but not in Darfur. Taking the lessons learned from Cambodia, China could orchestrate engagement with more than one actor in Darfur, such as the JEM and the Sudanese Liberation Army. To do so, China would need to reconsider its policy regarding the trade of arms and oil with the Sudanese government in the north. Once this issue has been addressed, China could address the issue of reconciliation. How it does so without losing face will need to be considered deliberately, but as a starting point, for example, it is meaningful for China to utilize a track two approach (such as discussions among academics, officials in non-government capacities, and civil society groups) to make an anthropological enquiry into the ways Sudanese local communities view the issue of reconciliation with outsiders.

\section{Conclusion}

This article has demonstrated that China's 'charm offensive' was successful in that its peacekeeping helped change negative local Cambodian perceptions of China to more positive ones. The impact of the 'charm offensive' vis-à-vis Cambodian populations was limited due to China's tao guang yang bui policy at the end of the Cold War. However, with the change in China's diplomacy that has an increasingly high profile, the impact of a Chinese 'charm offensive' on Sudanese local populations has significantly increased.

Observers might expect that Chinese peacekeepers could have gained favour among local peoples because the peacekeepers consisted mainly of engineering 
units, and because the engineers built social infrastructure such as roads and bridges - something visible and of direct benefit to the local populations. Contrary to such expectation, however, local Cambodian perceptions of China emerged as positive because the PRC had consistently supported the influential figure of Sihanouk over time, and because Cambodians had come to 'forgive' past Chinese policy apparently because of their socio-cultural background. If China had supported the Khmer Rouge only, it would have been difficult for Chinese peacekeepers to win local trust quickly, and to complete their peacekeeping contribution successfully. A Cambodian political culture also appeared to have helped overcome people's negative views towards China and led to forgiveness.

What do the lessons from Cambodia say about how China might consider policy changes to ensure the success of its peacekeeping operations in Sudan? First, China's image as a friend of the al-Bashir government needs to be addressed in the context of attempting to gain the trust of the local southern Sudanese and Darfurian people. China's peacekeeping contribution in Sudan cannot easily be reconciled with its provision of oil revenue and its arms sales to the Khartoum government. These are detrimental to the local perceptions of China, and reinforce the view that China is a friend of the Khartoum government and an opponent of the local people of southern Sudan and Darfur. The key to winning local trust is to be neutral in a broader political context and attentive to the needs of the various actors in the civil war. Local perceptions of China as a neutral actor in a broader political context have improved in southern Sudan since 2008. However, more effort is needed to improve local Darfurian perspectives of China's neutrality, by balancing between Khartoum and other actors in the civil war, such as the JEM and the Sudanese Liberation Army. Once this point is addressed, Chinese scholars and civil society groups could engage in discussion of the issue of reconciliation from a socio-anthropological perspective.

This discussion has important implications with regard to China's governmentoriented diplomacy based on the principle of sovereignty. While UN peacekeeping is useful for China's increasingly global 'charm offensive', it requires China to take a sophisticated approach to the principle of sovereignty of host states that are engaged in civil wars. Being a high-profile power in the twenty-first century, China can no longer afford to stick simply to the rigid interpretation of sovereignty. As discussed above in the case of Sudan, doing so inevitably leads to the local perception that China is a friend of the 'government', which antagonizes other warring factions that do not recognize the government's legitimacy. The sophisticated approach that China can take relates to how flexible the country can be in applying the principle of sovereignty to individual cases, by addressing the needs of other warring factions and maintaining neutrality in a broader political context.

\section{ACKNOWLEDGEMENTS}

I express sincere appreciation to the Cambodian Institute for Cooperation and Peace for its wonderful support during my research visit to Cambodia. I am especially grateful to H.R.H. Norodom 
Sirivudh, Chheang Vannarith and Neth Naro for their gracious help. I am also indebted to the members of the Royal Cambodian Armed Forces' College of Social Sciences and Languages, particularly Maj.-Gen. Dok Sopha and Col. Sok Pito for their kind support. I also thank Benny Widyono, Doung Viroth, and all the anonymous and non-anonymous interviewees who shared their valuable insights and so helped me prepare this article. My thanks also go to the University of Nottingham for the Fellows Recruitment Fund that enabled me to undertake field research in Cambodia and Australia, and to Catherine Gegout, Marc Lanteigne, Michael Pugh, Shogo Suzuki, Rod Thornton and Peter Trebilco for their helpful comments on earlier drafts of the article.

\section{NOTES}

1. Joshua Kurlantzick, 'Charm Offensive: How China's Soft Power Is Transforming the World', New Haven, CT: Yale University Press, 2007; Shogo Suzuki, 'Chinese Soft Power, Insecurity Studies, Myopia and Fantasy', Third World Quarterly, Vol.30, No.4, pp.779-93.

2. 'Chinese Oil Workers Kidnapped in Sudan's Kordofan', Sudan Tribune (Roubaix), 19 Oct. 2008 (at: www.sudantribune.com/spip.php?article28979); David Shinn, 'Chinese Involvement in African Conflict Zones', China Brief, Vol.9, No.7, 2009, pp.7-10.

3. David Keen, Complex Emergence, Cambridge: Polity Press, pp.48,208; Human Rights Watch, Sudan, Oil, and Human Rights, Brussels, 2003, pp.456-69; SaveDarfur, 'Briefing Paper: China in Sudan: Having It Both Ways', 18 Oct. 2007 (at: www.savedarfur.org/pages/policy_ paper/briefing_paper_china_in_sudan_having_it_both_ways/).

4. Daniel Large, 'China's Sudan Engagement: Changing Northern and Southern Political Trajectories in Peace and War', China Quarterly, 2009, p.614; US Holocaust Memorial Museum, 'Overview: Sudan' (at: www.ushmm.org/genocide/take_action/atrisk/region/sudan).

5. For surveys that indicate different figures, see Alex J. Bellamy, 'Responsibility to Protect or Trojan Horse?: The Crisis in Darfur and Humanitarian Intervention after Iraq', Ethics and International Affairs, Vol.19, No.2, 2006, p.31.

6. Ben Kiernan, The Pol Pot Regime: Race, Power and Genocide in Cambodia under the Khmer Rouge, 1975-79, 3rd edn, New Haven, CT: Yale University Press, 2008; Sophie Richardson, China, Cambodia, and the Five Principles of Peaceful Coexistence, New York: Columbia University Press, 2010.

7. Friedrich-Ebert-Stiftung, Cambodia 1975-2005 Journey through the Night, Bonn: FriedrichEbert-Stiftung, 2006, p.1.

8. See, e.g., Robert A. Rubinstein, 'Intervention and Culture: An Anthropological Approach to Peace Operations', Security Dialogue, Vol.36, No.4, 2005, pp.527-44; Stockholm International Peace Research Institute (SIPRI), SIPRI Yearbook 2009: Armaments, Disarmaments and International Security, Stockholm, 2009, p.105.

9. UN Department of Peacekeeping Operations, United Nations Peacekeeping Operations: Principles and Guidelines, 2008, p.36 (emphasis added).

10. George R. Lucas, 'The Morality of "Military Anthropology", Journal of Military Ethics, Vol.7, No.3, 2008, pp.165-87; Roberto J. Gonzalez, 'Towards Mercenary Anthropology? The New US Army Counterinsurgency Manual FM 3-24 and the Military-Anthropology Complex', Anthropology Today, Vol.23, No.3, 2007, pp.14-19.

11. SIPRI (see n.8 above), p.105.

12. Merriam Mashatt, Maj.-Gen. Daniel Long and James Crum, 'Conflict-Sensitive Approach to Infrastructure Development', Special Report No.197, US Institute of Peace, Jan. 2008 (at: www.usip.org/files/resources/sr197.pdf), p.12.

13. David Alexander Robinson, 'Hearts, Minds and Wallets: Lessons from China's Growing Relationship with Africa', Journal of Alternative Perspectives in the Social Sciences, 2009, Vol.1, No.3, p.863; interview with UK military personnel (location anonymized), 4 Aug. 2009, and telephone interviews with two peacekeepers for the African Union/UN Hybrid Operation in Darfur (UNAMID) (place anonymized), 16 Apr. 2009.

14. Many NGOs, whose strength lies in their neutrality, attempt to dissociate themselves from the military in humanitarian intervention, largely because local populations perceive the military as lacking neutrality. Daniel Byman, 'Uncertain Partners: NGO and the Military', Survival, Vol.43, No.2, 2001, pp.97-114; Fiona Terry, Condemned to Repeat?: The Paradox of Humanitarian Action, Ithaca, NY: Cornell University Press, 2002; Jacinta O'Hagan and 
Katherine Morton (eds), Humanitarianism and Civil-Military Relations in a Post-9/11 World, Canberra: Department of International Relations, Australian National University, 2009.

15. Stephanie Kleine-Ahlbrandt and Andres Small, 'China's New Dictatorship Diplomacy', Foreign Affairs, Vol.87, No.1, 2008, pp.38-56.

16. David Zweig suggests that China's policy on dictatorial regimes should be understood as 'amoral', rather than 'immoral': "'Resource Diplomacy" Under Hegemony: The Sources of Sino-American Competition in the $21^{\text {st }}$ Century?', Working Paper No.18, Center on China's Transnational Relations, Hong Kong University of Science and Technology, n.d. (at: www. cctr.ust.hk/materials/working_papers/WorkingPaper18_DavidZweig.pdf).

17. Neil Cooper, 'Review Article: On the Crisis of the Liberal Peace', Conflict, Security \& Development, Vol.7, No.4, 2007, pp.605-16; Michael Pugh, 'Accountability and Credibility: Assessing Host Population Perceptions and Expectations', in Cedric de Coning, Andreas Stensland and Thierry Tardy (eds), Beyond the New Horizon, Oslo: Norwegian Institute of International Affairs, 2010, pp.56-65.

18. Oliver P. Richmond, Peace in International Relations, London: Routledge, 2008, p.17.

19. Ibid., pp.21-2.

20. Paul Higate and Marsha Henry, 'Space, Performance and Everyday Security in the Peacekeeping Context', International Peacekeeping, Vol.17, No.1, 2010, pp.32-48; Béatrice Pouligny, Peace Operations Seen from Below: UN Missions and Local People, London: Hurst, 2006.

21. Stephen J. Morris, Why Vietnam Invaded Cambodia: Political Culture and the Causes of War, Stanford, CA: Stanford University Press, 1999.

22. For detailed discussions of the reasons why China supported both factions, see Kiernan (n.6 above) and Richardson (n.6 above), pp.89-106.

23. The first government in exile was formed after Gen. Lon Nol's coup d'état in 1970. Sihanouk formed a government in exile in Beijing, embracing the Khmer Rouge as one of the dominant forces in the exiled government as well as at the frontline of the civil war in Cambodia. The second government in exile was formed after Vietnam ousted the Khmer Rouge in December 1978, and Cambodia entered a period of civil war between the Vietnameseinstalled Heng Samrin government and the Coalition Government of Democratic Kampuchea (CGDK) - consisting of the Funcinpec Party led by Prince Sihanouk, the Khmer Rouge led by Khieu Samphan and the Khmer People's National Liberation Front, a conservative group led by Son Sann. The CGDK exile government was established at the Friendship Hotel in Beijing.

24. Richardson (see n.6 above), p.144.

25. 'Provisional Verbatim Record of the Three Thousand One Hundred and Forty-Third Meeting', UN doc., S/PV.3143, 30 Nov. 1992, p.4.

26. Interview with the Chief of the Department of Chheng Prey District, Kampong Cham Province, Cambodia, 11 Sept. 2009.

27. The People's Republic of Cambodia, Crime of Beijing Chinese Hegemony Enlargement and Servants Pol Pot, Eang Sary, Khieu Samphan during 1975-1978; Sophie Richardson and Brantly Womack, 'China, Cambodia, and the Five Principles of Peaceful Coexistnce', East-West Center, Honolulu,18 June 1010 (at: www.eastwestcenter.org/ewc-inwashington/events/previous-events-2010/june-18-dr-sophie-richardson-and-dr-brantly-womack/); interview with Youk Chhang, Documentation Centre of Cambodia Director, Phnom Penh, 7 Sept. 2009.

28. There was a sense of competition between China and Japan on the level of military contribution to UNTAC. Miwa Hirono, 'The Road to Recovery: The Spill-Over Effects of Multilateralism in Cambodia on Sino-Japanese Relations', in Victor Teo and Peng Er Lam (eds), Southeast Asia Between China and Japan, Newcastle Upon Tyne: Cambridge Scholars, Forthcoming.

29. This was because Japan had been criticized by domestic and international policymakers and analysts about merely contributing financial assistance to international security at the time of the First Iraq War. Therefore, more 'physical' - rather than merely financial - contributions were advocated among the Japanese.

30. Chien-Peng Chung, 'The "Good Neighbour Policy" in the Context of China's Foreign Relations', China, Vol.7, No.1, 2009, pp.109-10.

31. Interviews with: Lt Gen. John Sanderson, Force Commander UNTAC, Canberra, 31 Mar. 2009; Cambodian military personnel, Phnom Penh, 31 Aug. 2009; Cambodian goverment personnel, Phnom Penh, 31 Aug. 2009.

32. As of 16 Oct. 1992, China contributed 399, Japan 600, France 155, Poland 227 and Thailand 700. UNTAC Spokesman's Office, unpublished material, 1992.

33. Interviews with three village chiefs, Kompong Cham Province, Cambodia, 11 Sept. 2010. 
34. Sandra Whitworth, 'Gender, Race and the Politics of Peacekeeping', in Edward Moxon-Browne (ed.), A Future for Peacekeeping?, London: Macmillan, 1998, p.180.

35. Interviews with three village chiefs (see n.33 above). This is also confirmed by Lt Gen. John Sanderson (see n.31 above).

36. Interview with a village head, Kompong Cham Province, Cambodia, 11 Sept. 2009. Reports on humanitarian intervention suggest that the level of local trust and the kind of arms held by outsiders are correlated. For example, in the context of intervention in Afghanistan, the UK Ministry of Defence claims that 'winning the trust of the Afghan population is a key element in the battle against Taliban' and therefore 'we use foot patrols to make them feel less intimidated so we can make friends with them'. 'RAF Gunners Continue Protecting Cam Bastion', Defence News, 22 Feb. 2010 (at: www.mod.uk/DefenceInternet/DefenceNews/MilitaryOperations/ RafGunnersContinueProtectingCampBastion.htm).

37. Interviews with two civil society activists, Phnom Penh, 28 and 31 Aug. 2009; and a former UNTAC official, Phnom Penh, 4 Sept. 2009.

38. On the anthropological analytical framework for the interaction between local communities and outsiders, see Miwa Hirono, Civilizing Missions: International Religious Agencies in China, New York: Palgrave Macmillan, 2008, pp.36-40.

39. M. Taylor Fravel, 'China's Attitude toward U.N. Peacekeeping Operations since 1989', Asian Survey, Vol.36, No.11, 1996, pp.1102-21.

40. On China's flexible stance on the notion of sovereignty, see Stefan Stähle, 'China's Shifting Attitude towards United Nations Peacekeeping Operations', China Quarterly Vol.195, 2008, pp.631-55; Pang Zhongying, 'China's Non-intervention Question', Global Responsibility to Protect,Vol.1, No.2, 2009, pp.237-52; Allen Carlson, 'Helping to Keep the Peace (Albeit Reluctantly): China's Recent Stance on Sovereignty and Multilateral Intervention', Pacific Affairs, Vol.77, No.1, 2004, pp.9-27; Shogo Suzuki (see n.1 above); International Crisis Group (ICG), 'China's Growing Role in UN Peacekeeping', Asia Report, No.166, 2009.

41. On the distinction between traditional peacekeeping, peace enforcement and peace support operations, see Alex Bellamy, 'The Responsibility to Protect and the Problem of Military Intervention', International Affairs, Vol.84, No.4, 2008, pp.615-40. See Stähle (n.40 above, pp. 64042) for China's votes on relevant UN Security Council resolutions authorizing a variety of UN peace operations from 1992 to 2007.

42. However, it is important to note that 'consent' is not always given under the condition of perfect freedom. 'Consent' can be coerced or induced. Nicholas J. Wheeler, 'Operationalising the Responsibility to Protect: The Continuing Debate over Where Authority Should Be Located for the Use of Force', Report No.3, Responsibility to Protect, Norwegian Institute of International Affairs, 2008; David Roberts, 'A Dangerous Game: Managing Consent in the Cambodian UN Peacekeeping Operations', Studies in Conflict and Terrorism, Vol.21, No.1, 1998, pp.29-57.

43. Bates Gill and Chin-Hao Huang, China's Expanding Role in Peacekeeping: Prospects and Policy Implications, Stockholm: Stockholm International Peace Research Institute, 2009, pp.25-6; telephone interviews with UNAMID peacekeepers (see n.13 above).

44. Keen (see n.3 above), pp.48,208.

45. Mark Duffield, 'Foreword', in Michael Pugh, Neil Cooper and Mandy Turner, Whose Peace? Critical Perspectives on the Political Economy of Peacebuilding, Basingstoke: Palgrave Macmillan, 2011.

46. Email correspondence with a peacekeeper for UNAMID (location anonymized), 18 Sept. 2010.

47. 'China, Kenya Discuss New Corridor for Southern Sudan Oil', Sudan Tribune, 16 Oct. 2009 (at: www.sudantribune.com/spip.php?article32803); Barney Jopson, 'China and Kenya in Infrastructure Talks', Financial Times, 14 Oct. 2009 (at: fcaea.org/aid=287.phtml).

48. Ministry of Foreign Affairs of the People's Republic of China, 'Hand-over Ceremony of Antimalaria Medicines to Southern Sudan Held in Chinese Consulate General in Juba', 11 Aug. 2010 (at: www.fmprc.gov.cn/eng/wjb/zwjg/zwbd/t723295.htm).

49. 'China Should Prepare for Possible South Sudan Independence - Machar', Sudan Tribune, 19 Sept. 2010 (at: www.sudantribune.com/spip.php?page=imprimable\&id_article=36295); 'China's Zhou Yongkang hails China-Sudan relations', BBC Monitoring Asia Pacific, 18 Nov. 2009.

50. Daniel Large, 'China's Sudan Engagement: Changing Northern and Southern Political Trajectories in Peace and War', China Quarterly, Vol.199, 2009, p.610. 
51. Email correspondence with a peacekeeper for UNAMID (see n.46 above).

52. 'Rebels Tell China "Leave Sudan"', BBC News, 25 Oct. 2007 (at: news.bbc.co.uk/1/hi/ 7061066.stm).

53. Jonathan Holslag, 'China's Diplomatic Manoeuvring on the Question of Darfur', Journal of Contemporary China, Vol.17, No.54, 2008, p.84. 